\title{
KOMBINASI EKSTRAK ETANOL DAUN KEMANGI (Ocimum bacilicum L.) DAN DAUN SALAM (Syzygium polyanthum (Wight) Walp) SEBAGAI \\ ANTIINFLAMASI PADA TIKUS (Rattus norvegicus) JANTAN YANG DIINDUKSI KARAGEN
}

\section{Sukmawati, Rachmat Kosman, Nurwasi Saharuddin}

Fakultas Farmasi Universitas Muslim Indonesia

Email : sukmawati.sukmawati@umi.ac.id

\begin{abstract}
Inflammation is a normal protective response to tissue injury caused by physical trauma that could damage characterized by symptoms such as pain (dolor), heat (kalor), redness (rubor), swelling (tumor) and functional changes (fungsiolaesa). This research aimed to determine the anti-inflammatory effects of the ethanol extract combination of kemangi folium (Ocimum bacilicum L.) and salam folium (Syzygium polyanthum (Wight) Walp) in male rats (Rattus norvegicus) induced carrageen. This research used 15 rats divided into 5 groups: group I Na CMC (Naïve), group II Sodium Diclofenac (negative), group III was administered the ethanol extract of kemangi folium and salam folium with dose $125: 125 \mathrm{mg} / \mathrm{kgBW}$, group IV with dose of $125: 75 \mathrm{mg} / \mathrm{kgBW}$ and group $V$ with dose $250: 75 \mathrm{mg} / \mathrm{kgBW}$. The entire of administration was done orally. The measurement of male rat foot was performed every 30 minutes to 150 minutes. The data were statistically analyzed using One Way ANOVA followed by Post Hoc LSD test. The results showed that the ethanol extract of Kemangi folium with dose of $250 \mathrm{mg} / \mathrm{kgBW}$ and the ethanol extract of Salam folium with dose of $75 \mathrm{mg} / \mathrm{kgBW}$ had the effect of decreasing the edema volume of the rat foot effectively the same as anti-inflammatory drugs NSAID where the results of statistical analysis were obtained significance ( $p>0.05)$.
\end{abstract}

Key words : Inflammation, Kemangi Folium, Salam Folium, Sodium Diclofenac.

\section{PENDAHULUAN}

Inflamasi merupakan respon protektif normal terhadap luka jaringan yang disebabkan oleh trauma fisik, zat kimia yang merusak atau zat-zat mikrobiologi. Gejalanya seperti nyeri (dolor), panas (kalor), kemerahan (rubor), bengkak (tumor) dan perubahan fungsi (fungsiolaesa)..$^{1,2}$
Pengobatan yang selama ini dilakukan untuk menekan inflamasi yaitu penggunaan obat sintetik. Salah satunya adalah golongan obat antiinflamasi nonsteroid (OAINS) yang memiliki efek samping, seperti gangguan saluran cerna dan gangguan kardiovaskuler. ${ }^{3}$ Sehingga masyarakat beralih mencari 
Kombinasi ekstrak etanol daun kemangi (Ocimum bacilicum L.) dan daun salam (Syzygium polyanthum (Wight) Walp) sebagai antiinflamasi pada tikus (Rattus norvegicus) jantan yang diinduksi karagen

pengobatan alternatif yang lebih aman

dan potensial yaitu memanfaatkan

bahan alami.

Salah satu tumbuhan yang dapat dimanfaatkan sebagai anti inflamasi adalah daun kemangi (Ocimum bacilicum L). Daun kemangi terdapat tanin 4,6\%, flavonoid, steroid, minyak atsiri $2 \% .{ }^{4}$ Kandungan kimia flavonoid dilaporkan berefek anti virus, anti alergi, anti platelet, antiiflamasi, dan aktivitas antioksidan. ${ }^{5}$ Hasil penelitian Dwi Ayu (2015) menunjukkan bahwa ekstrak etanol kemangi 250 mg/kgBB mempunyai aktivitas antiinflamasi pada tikus. ${ }^{6}$

Tanaman lain yang memiliki aktivitas anti inflamasi adalah daun salam (Syzygium polyanthum (Wight) Walp). Hasil skrining fitokimia oleh Fatmawati (2011) menunjukkan bahwa daun salam mengandung senyawa alkaloid, flavonoid, saponin, tanin serta minyak atsiri yang terdiri dari sitral dan eugenol. ${ }^{7,8}$ Kandungan kimia yang berupa flavonoid ini diduga dapat memberikan efek antiinflamasi 9, dimana aktivitas antiinflamasinya dengan jalan menghambat aktivitas enzim siklooksigenase. ${ }^{10}$ Hasil penelitian Khusnul (2015) menunjukkan bahwa daun salam memiliki efek sebagai antiinflamasi, dimana dosis $125 \mathrm{mg} / \mathrm{kgBB}$ memiliki efek penurunan volume edema kaki tikus yang paling optimal. ${ }^{11}$

Adapun alasan kombinasi dari ekstrak etanol daun kemangi (Ocimum bacilicum $L$ ) dan daun salam (Syzygium polyanthum (Wight)Walp) yaitu untuk memaksimalkan efek antiiflamasi dari kombinasi tanaman tersebut yang didasarkan pada variasi dosis yang diuji sehingga diperoleh dosis yang efektif. Berdasarkan uraian tersebut diatas maka telah dilakukan penelitian tentang kombinasi ekstrak etanol daun kemangi (Ocimim bacilicum $L$ ) dan daun salam (Syzygium polyanthum (Wight) sebagai antiiflamasi pada tikus jantan yang diinduksi karagen.

\section{METODE PENELITIAN}

\section{Jenis Penelitian}

Jenis penelitian yang digunakan yaitu true eksperimental meliputi tiga komponen yaitu kontrol, randomisasi, dan replikasi. Rancangan penelitian yaitu pre-post test control group desain. ${ }^{12}$

\section{Alat dan Bahan}

Alat yang digunakan adalah alat suntik, alat gelas, plethysmometer LE 7500, timbangan analitik (Chiyco), dan timbangan kasar (O'hauss). Sedangkan bahan yang digunakan 
Kombinasi ekstrak etanol daun kemangi (Ocimum bacilicum L.) dan daun salam (Syzygium polyanthum (Wight) Walp) sebagai antiinflamasi pada tikus (Rattus norvegicus) jantan yang diinduksi karagen

adalah aquadest, daun kemangi

Pembuatan suspensi karagen $1 \%$

(Ocimum bacilicum L), daun salam

0,1 gram karagen dalam $10 \mathrm{~mL}$

(Syzygium polyanthum (Wight)Walp), etanol 70\%, natrium karboksimetil selulosa (Na-CMC), natrium klorida $0,9 \%$, suspensi karagen lambda $1 \%$, dan tablet natrium diklofenak.

\section{Prosedur Kerja}

Penyiapan dan pengolahan sampel

Sampel daun kemangi dan daun salam yang telah diperolehdikumpulkan, kemudian dicuci bersih terlebih dahulu setelah itu dipotong kecil-kecil. Selanjutnya dikeringkan dengan cara dianginanginkan tanpaterkena sinar matahari langsung.

Pembuatan ekstrak daun salam (Syzygium polyanthum (Wight) Walp) dan daun kemangi (Ocimum bacilicum $L$ )

Masing-masing simplisia ditimbang sebanyak 200 gram dan dimaserasi dengan etanol $70 \% 1000$ $\mathrm{mL}$ selama $5 \times 24$ jam, kemudian disaring dan ampasnya direndam kembali dengan cairan penyari yang baru, hasil penyarian yang diperoleh dipekatkan dengan menggunakan rotavapor sampai diperoleh ekstrak etanol pekat, kemudian diuapkan lagi hingga didapatkan ekstrak kental dan ditimbang. natrium klorida $0,9 \%$ fisiologis. Kemudian campuran tersebut dipanaskan

\section{Pembuatan suspensi Na-CMC 1\%}

Sebanyak 1 gram Na.CMC dimasukkan sedikit demi sedikit kedalam $50 \mathrm{~mL}$ air air suling panas $\left(70^{\circ} \mathrm{C}\right)$ sambil diaduk dengan menggunakan pengaduk elektrik hingga terbentuk larutan koloidal yang homogen, kemudian dicukupkan volumenya hingga $100 \mathrm{~mL}$ dengan air suling. ${ }^{13}$

\section{Pembuatan suspensi Natrium Diklofenak}

$5,118 \mathrm{mg}$ natrium diklofenak ditimbang dan digerus dalam lumpang. Selanjutnya ditambahkan $5 \mathrm{~mL}$ Na.CMC 1\% kemudian diaduk hingga homogen. Dicukupkan volumenya hingga $10 \mathrm{~mL}$.

\section{Pembuatan sediaan ekstrak etanol daun salam dan daun kemangi}

Pembuatan suspensi ekstrak etanol untuk dosis $125 \mathrm{mg} / \mathrm{kgbb}$ dibuat dengan cara ditimbang $125 \mathrm{mg}$ ekstrak. Kemudian disuspensikan dalam $10 \mathrm{~mL}$ Na.CMC. Sedangkan dosis $75 \mathrm{mg} / \mathrm{kgBB}$ dan $250 \mathrm{mg} / \mathrm{kgBB}$ dibuat dengan cara menimbang masing-masing $75 \mathrm{mg}$ dan $250 \mathrm{mg}$ 
Kombinasi ekstrak etanol daun kemangi (Ocimum bacilicum L.) dan daun salam (Syzygium polyanthum (Wight) Walp) sebagai antiinflamasi pada tikus (Rattus norvegicus) jantan yang diinduksi karagen

ekstrak kemudian disuspensikan

kemangi

masing-masing

dalam $10 \mathrm{~mL}$ Na.CMC.

\section{Perlakuan terhadap hewan coba}

Hewan uji dipuasakan selama

18 jam sebelum perlakuan kemudian ditimbang berat badannya dan diukur volume kaki menggunakan pletismometer sebagai volume awal $\left(\mathrm{V}_{0}\right)$. Semua hewan uji dibuat edema dengan menginjeksikan karagen 1\% sebanyak $0,1 \mathrm{~mL}$ secara subplantar. Setelah 3 jam kemudian, dilakukan pengukuran volume inflamasi kaki hewan uji yang telah diinduksi dengan karagen. Hewan uji dibagi menjadi 5 kelompok perlakuan, masing-masing kelompok terdiri dari 3 hewan uji. Perlakuannya adalah sebagai berikut:

a. Kelompok 1 diberikan Na.CMC sebagai kontrol negatif.

b. Kelompok 2 diberikan suspensi natrium diklofenak sebagai kontrol positif

c. Kelompok 3 diberikan ekstrak etanol daun salam dan daun
$125 \mathrm{mg} / \mathrm{kgBB}$.

d. Kelompok 4 diberikan ekstrak etanol daun kemangi $125 \mathrm{mg} / \mathrm{kgBB}$ dan ekstrak etanol daun salam $75 \mathrm{mg} / \mathrm{kgBB}$.

e. Kelompok 5 ekstrak etanol daun kemangi 250mg/kgBB dan ekstrak etanol daun salam $75 \mathrm{mg} / \mathrm{kgBB}$.

Seluruh pemberian dilakukan secara oral. Pengukuran telapak kaki tikus (Rattus novergicus) jantan dilakukan setiap 30 menit sampai 150 menit. Setelah itu dicatat volume kaki pada setiap masing-masing perlakuan.

\section{Analisis data}

Data yang diperoleh dari hasil pengukuran volume kaki tikus dianalisa secara statistik menggunakan program SPSS (Statistical Product and Service Solutions) dan metode one way anova. Kemudian dilanjutkan dengan uji LSD untuk melihat perbedaan antar perlakuan.

\section{HASIL PENELITIAN}

Tabel 1. Hasil rata-rata pengukuran volume edema $(\mathrm{mL})$

\begin{tabular}{ccccccc}
\hline \multirow{2}{*}{ Kelompok } & \multicolumn{5}{c}{ Volume edema $(\mathbf{m L})$ setelah perlakuan (menit) \pm SD } \\
\cline { 2 - 7 } & $\mathbf{0}$ & $\mathbf{3 0}$ & $\mathbf{6 0}$ & $\mathbf{9 0}$ & $\mathbf{1 2 0}$ & $\mathbf{1 5 0}$ \\
\hline Kontrol Negatif & $2,82 \pm 0,13$ & $3,03 \pm 0,05$ & $3,14 \pm 0,04$ & $3,29 \pm 0,09$ & $3,39 \pm 0,06$ & $3,47 \pm 0,11$ \\
Kontrol Positif & $3,23 \pm 0,15$ & $3,23 \pm 0,15$ & $3,23 \pm 0,15$ & $3,23 \pm 0,15$ & $3,23 \pm 0,15$ & $2,08 \pm 0,15$ \\
EEKS 125: $125 \mathrm{mg} / \mathrm{kgBB}$ & $2,91 \pm 0,11$ & $2,51 \pm 0,09$ & $2,48 \pm 0,09$ & $2,37 \pm 0,02$ & $2,26 \pm 0,04$ & $2,19 \pm 0,04$ \\
EEKS 125 : 75 mg/kgBB & $2,91 \pm 0,07$ & $2,57 \pm 0,14$ & $2,46 \pm 0,12$ & $2,35 \pm 0,05$ & $2,29 \pm 0,12$ & $2,17 \pm 0,06$ \\
EEKS 250: 75 mg/kgBB & $3,57 \pm 0,05$ & $3,57 \pm 0,05$ & $3,57 \pm 0,05$ & $3,57 \pm 0,05$ & $3,57 \pm 0,05$ & $3,57 \pm 0,05$ \\
\hline Ket : EEKS (ekstrak etanol daun kemangi Salam)
\end{tabular}

Ket : EEKS (ekstrak etanol daun kemangi Salam) 
Kombinasi ekstrak etanol daun kemangi (Ocimum bacilicum L.) dan daun salam (Syzygium polyanthum (Wight) Walp) sebagai antiinflamasi pada tikus (Rattus norvegicus) jantan yang diinduksi karagen

Tabel 2. Hasil rata-rata persentase penurunan volume edema setelah pemberian sediaan uji

\begin{tabular}{cc}
\hline Kelompok & Persentase penurunan \\
\hline Kontrol Negatif & $-23,35 \%^{a}$ \\
Kontrol Positif & $30,27 \%^{\mathrm{b}}$ \\
EEKS $125: 125 \mathrm{mg} / \mathrm{kgBB}$ & $24,67 \%$ \\
EEKS $125: 75 \mathrm{mg} / \mathrm{kgBB}$ & $25,31 \%$ \\
EEKS 250: $75 \mathrm{mg} / \mathrm{kgBB}$ & $28,11 \%$ \\
\hline
\end{tabular}

Data disajikan dalam bentuk Mean

a $P<0.05$ dengan semua kelompok perlakuan ( $L S D$ test)

b $\mathrm{P}>0.05$ dengan ketiga kelompok dosis kombinasi ( $L S D$ test)

Data rata-rata persentase penurunan volume edema kelompok kombinasi dosis dengan kontrol diplot dalam bentuk diagram gambar 1 berikut ini :

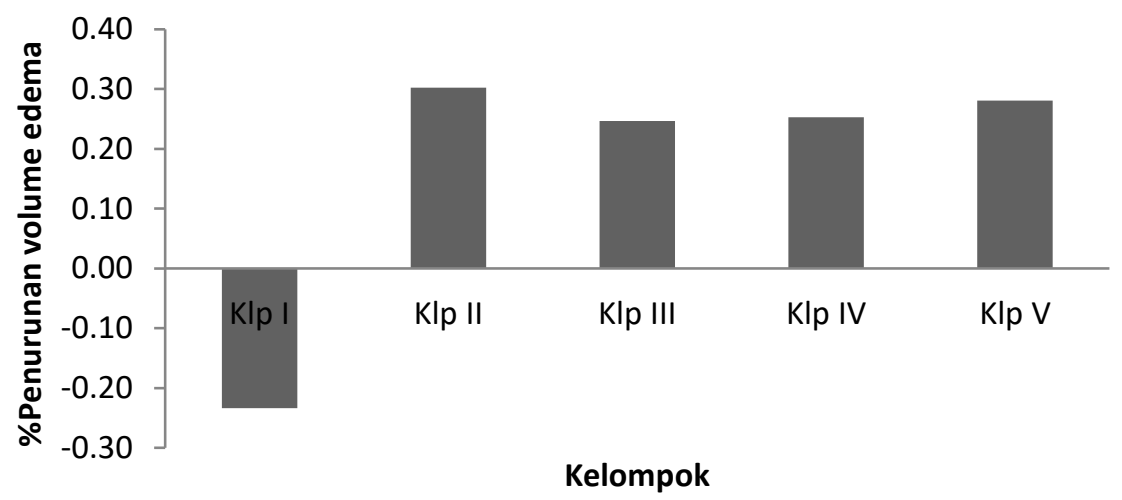

Gambar 1. Diagram rata-rata \% penurunan volume edema pada hewan uji.

\section{PEMBAHASAN}

Pada penelitian ini, dilakukan pengujian efek antiinflamasi kombinasi ekstrak etanol daun kemangi (Ocimum bacilicum $L$ ) dan daun salam (Syzygium polyanthum (Wight) Walp) terhadap tikus (Rattus novergicus) jantan yang diinduksi karagen1\%. Penelitian ini bertujuan untuk mengetahui efek antiinflamasi kombinasi ekstrak etanol daun kemangi danekstrak etanol daun salam untuk menentukan dosis ekstrak yang efektif dengan penurunan dosis tertentu sebagai antiinflamasi.

Pengujian efek antiinflamasi dilakukan berdasarkan parameter penurunan volume edema pada telapak kaki tikus yang diinduksi karagen 1\%secara subplantar karena pada dosis tersebut sudah dapat menimbulkan edema yang dapat teramati secara jelas. Karagen sebagai senyawa iritan menginduksi 
Kombinasi ekstrak etanol daun kemangi (Ocimum bacilicum L.) dan daun salam (Syzygium polyanthum (Wight) Walp) sebagai antiinflamasi pada tikus (Rattus norvegicus) jantan yang diinduksi karagen

terjadinya cedera sel melalui pelepasan prostaglandin yang mengawali proses inflamasi. Pengujian inflamasi dengan menggunakan karagen merupakan pengujian yang sederhana, mudah dilakukan dan sering dipakai. Karagen digunakan sebagai penginduksi karena mudah diterima oleh fisiologis tubuh sehingga respon inflamasi cepat terjadi dan pembengkakannya lebih nyata sehingga mudah untuk diamati. Keuntungan lain dari penggunaan karagen adalah tidak menimbulkan kerusakan jaringan, dan tidak menimbulkan bekas. ${ }^{14}$

Sampel yang digunakan pada penelitian ini adalah ekstrak etanol daun kemangi (Ocimum bacilicum L) dan ekstrak etanol daun salam (Syzygium polyanthum (Wight) Walp). Dimana telah diteliti oleh Dwi Ayu (2015) menunjukkan bahwa ekstrak etanol daun kemangi mempunyai aktivitas antiinflamasi yang efektif dosis $250 \mathrm{mg} / \mathrm{kgBB} .{ }^{6}$ Kemudian hasil penelitian Khusnul (2015) menunjukkan bahwa daun salam memiliki efek sebagai antiinflamasi yang efektif dosis $125 \mathrm{mg} / \mathrm{kgBB} .{ }^{11}$

Pada penelitian ini hewan uji yang digunakan adalah tikus (Rattus norvegicus) jantan dengan umur 2-3 bulan dengan bobot badan 150-200 gram. Yang sebelumnya diadaptasikan selama 2 minggu tujuan dari adaptasi yaitu untuk mengkondisikan tikus dengan lingkungan yang baru sehingga dapat mengurangi faktor stress yang mungkin mempengaruhi hasil penelitian nantinya. Digunakan tikus jantan berdasarkan pertimbangan dimana tikus jantan tidak memiliki hormon estrogen serta kondisi hormonal pada tikus jantan relatif stabil dibandingkan dengan tikus betina. Tingkat stres tikus betina lebih tinggi dibandingkan dengan tikus jantan sehingga dapat mengganggu absorbsi obat dan berpengaruh pada hasil pengujian. ${ }^{15}$

Pengujian aktivitas antiinflamasi dibagi dalam 5 kelompok masingmasing 3 hewan perlakuan yaitu kelompok I Na.CMC 1\%, hal ini bertujuan untuk melihat apakah Na.CMC tidak memberikan efek fisiologis bagi hewan coba serta alasan penggunaan Na.CMC dilihat dari pembawa sediaan uji lainnya. Kelompok II obat Natrium diklofenak 5,118 mg yang disuspensikan ke dalam $10 \mathrm{~mL}$ Na.CMC dan kelompok III diberikan ekstrak etanol daun kemangi dosis $125 \mathrm{mg} / \mathrm{kgBB}$ dan ektrak etanol daun salam dosis 125 
Kombinasi ekstrak etanol daun kemangi (Ocimum bacilicum L.) dan daun salam (Syzygium polyanthum (Wight) Walp) sebagai antiinflamasi pada tikus (Rattus norvegicus) jantan yang diinduksi karagen

$\mathrm{mg} / \mathrm{kgBB}$, kelompok IV diberikan ekstrak etanol daun kemangi dosis $125 \mathrm{mg} / \mathrm{kgBB}$ dan ekstrak etanol daun salam dosis $75 \mathrm{mg} / \mathrm{kgBB}$, kelompok V diberikan ekstrak etanol daun kemangi dosis $250 \mathrm{mg} / \mathrm{kgBB}$ dan ektrak etanol daun salam dosis $75 \mathrm{mg} / \mathrm{kgBB}$. Sebelum terapi masing-masing hewan uji di berikan sediaan induksi 0,1 mL karagen $1 \%$ secara subplantar sebagai induktor udem. Sebelum perlakuan hewan uji dipuasakan selama 18 jam tetapi masih diberikan minum dengan tujuan agar tidak terjadi interaksi yang tidak diinginkan, sehingga diharapkan obat yang diberikan dapat diserap dengan cepat.Semua perlakuan diberikan secara oral, dan setelah perlakuan pengukuran penurunan volume edema kaki tikus dilakukan setiap selang 30 menit sampai 150 menit.

Pada awal penelitian, volume telapak kaki masing-masing hewan uji diukur telapak kaki dengan alat pletismometer tujuannya adalah untuk mengetahui seberapa besar efek obatobat antiinflamasi tersebut mengurangi bengkak/peradangan pada telapak kaki tikus yang telah diinduksi. Data rata-rata hasil pengukuran volume edema ekstrak etanol daun kemangi dan daun salam dan pembandingnya

dapat dilihat pada tabel 1. Selanjutnya data hasil rata-rata dari tabel 1 kemudian dibuat persentase penurunan yang dapat dilihat pada tabel 2 dan gambar 1, yang menunjukkan pada kelompok Na.CMC (kontrol negatif) tidak mengalami penurunan volume edema tetapi mengalami peningkatan volume edema dikarenakan $\mathrm{Na}$. CMC sebagai larutan kontrol dan sebagai pelarut obat yang tidak memberikan efek antiiflamasi. ${ }^{16}$ Presentase penurunan yang besar yaitu kelompok natrium diklofenak (kontrol positif). Natrium diklofenak merupakan derivat fenilasetat yang kuat antiradangnya dengan efek samping yang relatif ringan dibandingkan obat jenis lainnya. Obat ini bekerja dengan jalan menghambat aktivitas enzim siklooksigenase sehingga tidak terbentuk mediator inflamasi. ${ }^{10}$

Dari hasil penelitian penurunan volume edema kemudian diolah secara statistik menggunakan SPSS untuk dapat menganalisis perbedaan antar kelompok. Maka dilakukan analisis lanjutan yaitu uji Post Hoc dengan metode $L S D$. Hasil uji tersebut menunjukkan bahwa kelompok kontrol negatif (Na.CMC) memiliki efek yang berbeda nyata terhadap semua 
Kombinasi ekstrak etanol daun kemangi (Ocimum bacilicum L.) dan daun salam (Syzygium polyanthum (Wight) Walp) sebagai antiinflamasi pada tikus (Rattus norvegicus) jantan yang diinduksi karagen

kelompok $(p<0,05)$ (dapat dilihat pada

tabel 2). Hal ini menunjukkan bahwa sediaan Na.CMC tidak memiliki efek sebagai antinflamasi.

Dari hasil uji statistik, kelompok pembanding Natrium diklofenak dengan ekstrak etanol daun kemangi salam(EEKS) dosis 125:125mg/kgBB serta dosis 125:75 mg/kgBB berbeda nyata $(p<0,05)$. Hal ini menunjukkan efektivitas yang berbeda atau tidak samadengan obat/pembanding yaitu tidak menurunkan volume edema, kelompok Natrium diklofenak dengan EEKS dosis 250:75 mg/kgBB tidak berbeda nyata $(p>0,05)$. Hal ini menunjukkan efektivitas yang sama dengan obat/pembanding dalam menurunkan volume edema. Semua kelompok EEKS dosis 125:125 $\mathrm{mg} / \mathrm{kgBB}$ dengan EEKS dosis 125:75 $\mathrm{mg} / \mathrm{kgBB}$ dan kelompok EEKS dosis 125:75 mg/kgBB dengan EEKS dosis 250:75 mg/kgBB tidak berbeda nyata $(p>0,05)$ ini menunjukkan efektifitas yang dapat menurunkan volume edema.

Namun jika dilihat dari persen penurunan menunjukkan bahwa ekstrak etanol daun kemangi dosis $250 \mathrm{mg} / \mathrm{kgBB}$ dengan ekstrak etanol daun salam dosis $75 \mathrm{mg} / \mathrm{kgBB}$ menunjukkan penurunan volume edema pada telapak kaki tikus yang lebih tinggi (28,11\%) dibandingkan dengan dosis 125:125 mg/kgBB $(24,67 \%)$ dan dosis $125: 75 \mathrm{mg} / \mathrm{kgBB}$ $(24,64 \%)$.

Sifat antiiflamasi daun kemangi disebabkan adanya kandungan kimia diantaranya minyak atsiri (0,05\%) mengandung sitral dan euganol, tanin dan flavanoid. Jenis flavanoid yang diketahui berperan dalam antiiflamasi adalah orientin dan vinencin. ${ }^{17}$ Sedangkan daun salam mengandung minyak atsiri $(0,05 \%)$ mengandung sitral dan euganol, tanin dan flavanoid. Jenis flavanoid yang diketahui berperan dalam antiinflamasi adalah quercetin, dan kaempferol. ${ }^{18}$

Efektivitas ekstrak sebagai antiinflamasi disebabkan adanya kandungan kimia flavonoid. Menurut Sativa (2014) jenis flavonoid yang diketahui berperan dalam aktivitas antiinflamasi salah satunya adalah quercetin. Senyawa ini memiliki mekanisme antiinflamasi dengan menghambatenzim siklooksigenase sehingga tidak membentuk mediator inflamasi. ${ }^{18}$ Mekanisme lain dari flavonoid melalui dua cara yaitu dengan menghambat permeabilitas kapiler dan menghambat metabolisme arakidonat dimana flavanoid ini 
Kombinasi ekstrak etanol daun kemangi (Ocimum bacilicum L.) dan daun salam (Syzygium polyanthum (Wight) Walp) sebagai antiinflamasi pada tikus (Rattus norvegicus) jantan yang diinduksi karagen

berperan penting dalam menjaga

(Wight) Walp) memiliki efek sebagai permeabilitas serta meningkatkan resistensi pembuluh darah kapiler. Oleh karena itu flavanoid digunakan dalam keadaan patologis seperti terjadinya kerusakan pembuluh darah akibat radang menyebabkan peningkatan permeabilitas kapiler sehingga darah akan keluar dari kapiler jaringan. ${ }^{19}$

Berdasarkan hasil penelitian, menunjukkan bahwa kombinasi ekstrak etanol daun kemangi dosis $250 \mathrm{mg} / \mathrm{kgBB}$ dan ekstrak etanol daun salam dosis $75 \mathrm{mg} / \mathrm{kgBB}$ memiliki efek penurunan volume edema kaki tikus yang efektif dengan persentase penurunan volume edema paling tinggi sebesar $28,11 \%$ serta didukung oleh hasil analisa statistik untuk dibandingkan dengan obat Natrium diklofenak dimana $(p>0,05)$ tidak berbeda nyata hal ini menunjukkan efektifitas yang sama dengan obat atau pembanding dalam menurunkan volume edema.

\section{KESIMPULAN}

Berdasarkan hasil penelitian dan pembahasan disimpulkan kombinasi ekstrak etanol daun kemangi (Ocimim bacilicium L.) dan daun salam (Syzygium polyanthum antiinflamasi. Kombinasi ekstrak etanol daun kemangi dosis $250 \mathrm{mg} / \mathrm{kgBB}$ dan ekstrak etanol daun salam dosis 75 $\mathrm{mg} / \mathrm{kgBB}$ memiliki efek penurunan volume edema kaki tikus yang efektif dengan presentase penurunan $28,11 \%$ dan secara statistik tidak berbeda dengan natrium diklofenak $(p<0,05)$.

\section{DAFTAR PUSTAKA}

1. Mycek MJ. Harvey RA, Champe PC. Farmakologi ulasan bergambar. Jakarta : Widya Media, 2001.

2. Megawati JN, Wulur A, Yudistira A. Uji efek antiinflamasi daun suji (Dracaena angustifolia Roxb) terhadap edema kaki tikus putih jantan galur wistar. Pharmacon.2013;2:15.

3. Fitriyani A, Winarti L, Muslichah $S$,. Uji antiinflamasi ekstrak metanol daun sirih merah (Piper crocatum Ruiz \& Pav) pada tikus putih. Majalah Obat Tradisional. 2011;16:35.

4. Sutrisna EM et al. Potensi efek antipiretik daun kemangi (Ocimum sanctum L) dan daun dewa (Gynura pseudochina (L) D.C). Surakarta : Fakultas Farmasi Universitas Muhammadiah Surakarta, 2009.

5. Heim KE, Tagliaferro AR, Bobilya D J. Flavanoid antioxidants : chemistru,metabolisme and structure-activy relationship. J Nutr Biochem. 2002;13 (10):572-584.

6. Restiani DA, Umi Y, Siti H. Uji Aktivitas Antiiflamasi dari Ekstrak 
Kombinasi ekstrak etanol daun kemangi (Ocimum bacilicum L.) dan daun salam (Syzygium polyanthum (Wight) Walp) sebagai antiinflamasi pada tikus (Rattus norvegicus) jantan yang diinduksi karagen

Etanol Herba Kemangi (Ocimum Americanum L.) Terhadap Tikus Jantan Wister. Bandung: Fakultas Mipa Unisba, 2015.

7. Fatmawati E. Ekstrak Etanol Daun Salam dan Fraksinya sebagai Inhibitor Alfa-Amilase (Skripsi). Bogor: Fakultas MIPA IPB, 2011.

8. Dalimartha S. AtlasTumbuhan Obat Indonesia. Jakarta: Edisi II Trubus Agriwidya, 2000.

9. Markham KR and Anderson OM. Flavonoid Chemistry, Biochemistry and Application Bocaraton. CRP Press and Taylor \& Francis Group; 2006.

10. Meltyza E, Anita IR, Bhekti RS. Perbandingan Efek Antiinflamasi Ekstrak Etanol Kunyit Putih (Curcuma zedoaria) Dengan Natrium Diklofenak Pada Tiukus Yang Diinduksi Dengan Karagen. 2014.

11. Khatimah K. Uji Efek Antiinflamasi Ekstrak Etanol Daun Salam (syzygium polyanthum (wight) walp) Terhadap Tikus (rattus norvegicus)Jantan Yang Diinduksi Karagen (Skripsi). Makassar: Fakultas Farmasi Universitas Muslim Indonesia; 2015.

12.Zainuddin M. Metodologi Penelitian: Kefarmasiaan dan Kesehatan. Surabaya: Airlangga University Press; 2011.

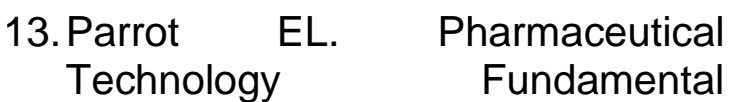

Pharmaceutics. Minnepolis: Burgess Publishing Company; 1979.

14. Yuslinda E, Hasti S, Wati E. Efek antiinflamasi fraksi heksan dan fraksi etil asetat daun alpukat (Persea americana Mill) pada tikus (Rattus norvegicus) putih jantan, J Sains Tek Far:2015;16:2.

15. Suhendi A, Nurcahyanti, Muhtadi, Sutrina EM. Antihyperurisemia activity of water extract of black seed (Colues ambonicus Lour) in balb-c mice and its standardization, Majalah Farmasi Indonesia: 2011;22(2):77-84.

16. Ditjen POM. Sediaan Galenik. Jakarta: Departemen Kesehatan RI, Indonesia; 1986.

17. Sangar SM, Yance D, Wong RK. Natural health products that inhibit angiogenesis: a potential source for investigational new agents to treat cancer-Part 1. Current Oncology [serial online] [cited 2009 January 27]; 13(1): 14-26.

18. Sativa O, Sulstri E, Yuliet. Uji aktivitas antiinflamasi gel ekstrak buah kaktus (Opuntia elatior Mill.) pada tikus (Rattus norvegicus) yang diinduksi lamda karagen. Jurnal of Natural Science:2014, 3:2.

19. Kurniawati A. Uji aktivitas anti inflamasia ekstrak metanol Graptophyllum griff pada tikus putih. Majalah Kedokteran Gigi Edisi Khusus Temu IImiah Nasional IV: 2005;167-170 